\title{
An image of the loss of pre-university school enrollment during the education levels
}

\author{
Marian Zaharia ${ }^{1}$ \\ ${ }^{1}$ Association for Democracy, Education, Respect, Targu-Jiu, Romania \\ E-mail: marianzaharia53@gmail.com
}

\begin{abstract}
The education in Romania is facing in the last decades a series of problems both at system level and within its components. One of these problems is the loss of pre-university school population from level 1 to level 3 of education. They are differentiated by gender as well as by macroregions, development regions and counties. Based on these considerations, the paper presents the magnitude of the losses of school population during the transition from one level of education to another and highlights the extent of this phenomenon during the period 2009 - 2017. Thus at national level, among those who were in 2009 in the level 1 of training, in 2017 in level 3 of training their number had decreased by $39 \%$ for the male school population and by $15 \%$ for the female gender school population. The paper also highlights the fact that the losses of pre-university school population during the three levels of education differ fundamentally from one county to another, reaching in some cases over $60 \%$.
\end{abstract}

Keywords: pre-university school population, education levels, cluster analysis, Romania.

\section{Introduction}

One of the most important pillars of sustainable development at regional and central level is education. From the pre-school level and especially at the pre-university level, through its social function based on the principles and norms of teaching [1], it must form the attitudes and abilities of the future members of the society [2] so as to lead to a positive trend of social and economic development. Otherwise, a deficient educational and informational level can generate discontinuities and instability at national and even global level [3].

Creating knowledge-based economies involves ensuring a balance between the level of education and the labor market. Researching the balance between supply and demand on this market Nistoreanu [4] emphasized the important role of educational marketing, the more so, as much as in competitive economies, entrepreneurial education is essential for understanding and overcoming the difficulties of actions in complex competitive markets [5].

Unfortunately, as Corbu pointed out [6], the transition from a centralized economy, until 1989, to a competitive economy produced in Romania a complete disruption of the labor market. The reforms adopted after 1989, however, did not have the expected results of education, not paying the necessary attention neither from the perspective of human resources nor from the point of view of infrastructure [7]. In a study published in 2013, Tusa, Voinia and Dumitrascu [8] stressed that $62.70 \%$ of the school principals in question considered that they are not sufficiently prepared for effective business 
management, given the level of Involvement of teachers in the education of students is a fundamental element in the educational process [9].

On the other hand, education, its level, has an impact on the quality of life. Mascu [10], in his analysis, underlined the importance of implementing in the pre-university education of the modern systems of quality control in accordance with the requirements of the European Union. Moreover, given the fact that Europe 2020: A new European strategy for growth and jobs sets among its objectives to ensure a employment rate of $75 \%$ by 2020 and to reduce school drop-out to $10 \%$, preuniversity education and implicitly the process management in pre-university education can be a way to contribute to the achievement of these objectives [11].

Taking into account these aspects, the first part of the paper analyzes the losses of pre-university school population in the process of transition from one level of education to another, between 2009 and 2017. The analysis is carried out in parallel, on the two genres (male and female), starting from the level of macro-regions and development regions in Romania.

In the second part of the paper, in order to capture the particularities and territorial similarities, a cluster analysis is carried out taking into account the characteristics of the losses of pre-university population at county level.

\section{Metodology}

The data series used in the analysis of the losses of pre-university school population by gender are based on the statistical research conducted by NIS [12] at the beginning of the school year in the preuniversity education units. According to ISCED [13] they are: primary education (level 1), secondary school (level 2) and high school (level 3). The data series refer to the pre-university school population, by genres, development regions and counties [14], in the years 2009, 2013 and 2017.

Analyzes regarding the loss of pre-university school population during the transition from one level of education to another were carried out on three levels of resolution.

- At Romania level, the analyzes were performed in absolute values by gender (male and female).

- At the level of development regions, the analyzes were aimed at comparative analysis of the percentages of the pre-university school population by gender and development regions in 2009 (level 1 education) and 2017 (level 3 education).

- At the county level, the similarities and disparities between the counties regarding the weight of school population losses were analyzed during the transition from one level of education to another.

The characteristics of the variables used are presented in table 1.

Tabele 1. The variables used to analyze the losses of pre-university school population during the transition from one level of education to another

\begin{tabular}{lll}
\hline Indicator & \multicolumn{1}{c}{ Semnificație } \\
\hline M_PR_12 & $\begin{array}{l}\text { The ratio between the number of male students who were no longer in } \\
\text { level } 2 \text { in 2013, and the number of those who were in level } 1 \text { in } 2009 \\
\text { The ratio between the number of male students who in } 2017 \text { were no } \\
\text { longer in level } 3 \text { of education, and the number of those who in } 2013 \\
\text { were in level } 1 \text { of education }\end{array}$ & $\%$ \\
The ratio between the number of female students who were no longer in \\
level 2 of education in 2013 and the number of those who were in level \\
1 of education in 2009
\end{tabular}


Thoth Publishing House

To highlight the similarities and disparities between counties, hierarchical cluster methodology was used in the analysis. To generate clusters Euclidian distance and Average linkage between groups method were used.

Validation of the results was performed with Levene Statistical and ANOVA methodology, Welch and Brown-Forsythe Robust Tests, as well as Test of Homogeneity of Variances, for Confidence level 95\% (significance level $\alpha=0.05$ ).

\section{Rezults and discusions}

During the analyzed period, during the transition from one level of education to another there were losses of the pre-university school population both at the level of Romania and at the levels of the development regions and counties.

\subsection{An overview}

At the level of Romania, both the male and female school population registered significant decreases (figure 1). Thus, if in 2009 the male school population included in level 1 of education was 433,281 persons, in 2013, the year in which it was in level 2 of education, it decreases to 407,787, which corresponds to a loss of approximately 25 thousand persons $(25,494)$, which represents a loss of $5.88 \%$. In 2017, of those who were included in level 2 of education in 2013, over 100 thousand people (24.59\%) were no longer found in level 3 of education. Consequently, of the 433,281 persons included in 2009 in level 1 of education, only 307,642 persons (71.0\%) were in level 3 of education.
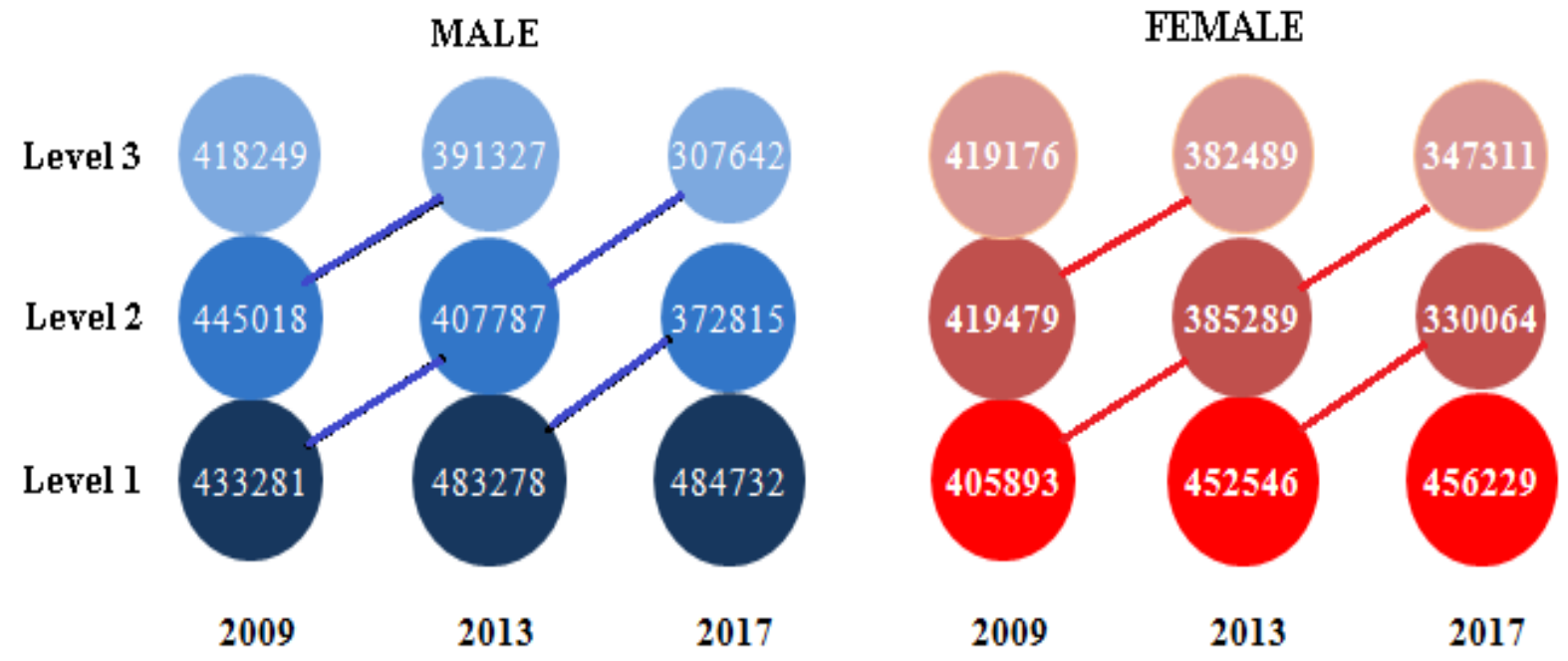

Figure 1. Evolutions of the pre-university male and female school population by education levels between 2009 and 2017

Worrying is that between 2013 and 2017 the trend has increased. Compared to 2013, the year in which the school population included in level 1 of education was 483278 persons, in 2017 only $77.14 \%$ of them were in level 2 of education, the loss being of $22.86 \%$, almost 4 times more than in 2009 - 2013.

In the case of the female school population, in 2009 the number of the population included in level 1 of education was 452546 persons. In 2013, 330064 persons had passed the level 2 education, with about 20 thousand less (which corresponds to a loss of 5.07\%. In 2017, from the female school population that in 2013 were included in level 2 education, 37978 persons $(9.86 \%)$ were no longer found in education level 3. However, in absolute and relative terms, the losses are lower than in the case of the male population: $14.43 \%$ (74968 persons), in the case of the female school population compared to $29 \%$ ( 153836 persons), in the case of the male school population. 
Thoth Publishing House

\subsection{Evolutions at the level of development regions}

Between 2009 and 2017, there were changes both in the hierarchy of development regions in terms of pre-university school population weight and in the weighted values recorded.

Thus, in the case of the weight of the male school population at level 1 of education in 2009, in the total of the same population registered at the level of Romania (figure 2), the North-East region (20\%) was first, followed by the South Muntenia regions ( 15\%) and the North-West and South-East group of regions (13\%). The lowest percentages were in South-East Oltenia (10\%), West (9\%) and BucharestIlfov $(8 \%)$.
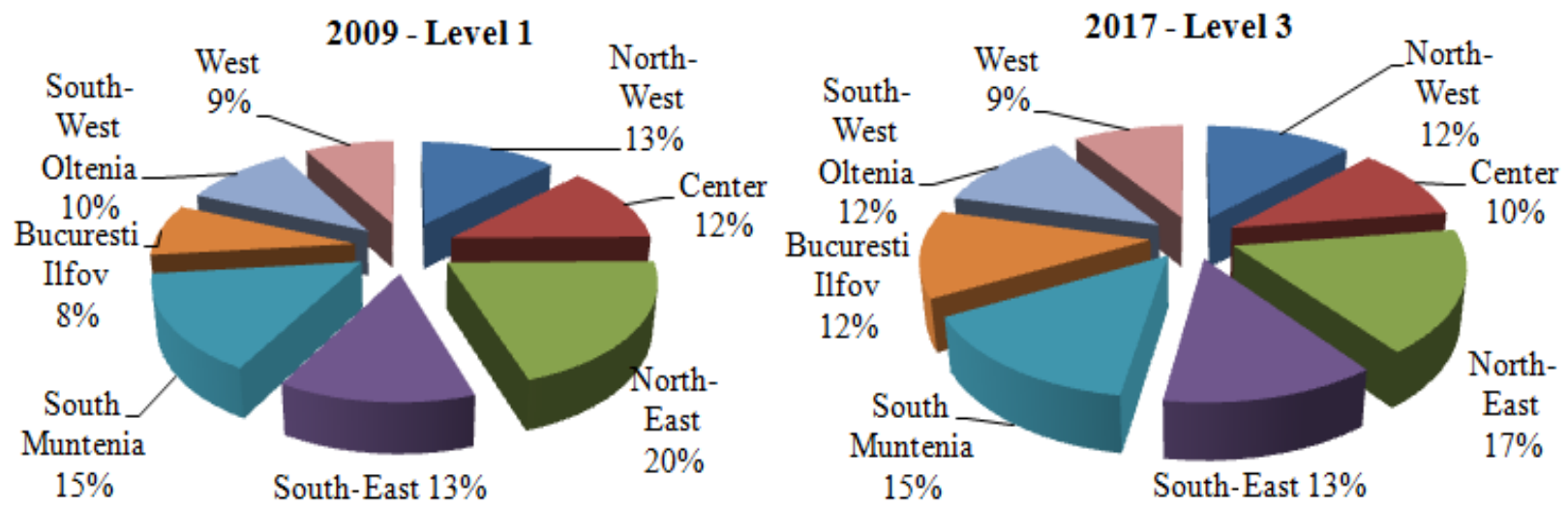

Figure 2. Evolutions of the weight of the male pre-university school population by development regions from Level 1 (2009) to Level 3 (2017)

After 8 years, part of the population which was in 2009 in level 1 of education, in 2017 is in level 3 of education. Given that both the hierarchy and the weights recorded changes, this process did not take place uniformly in all the development regions.

Thus, a particular feature is the Bucharest-Ilfov development region where, the increase by 4 percentage points is due primarily to the sustained development of this region, which has led to attracting population from other development regions.
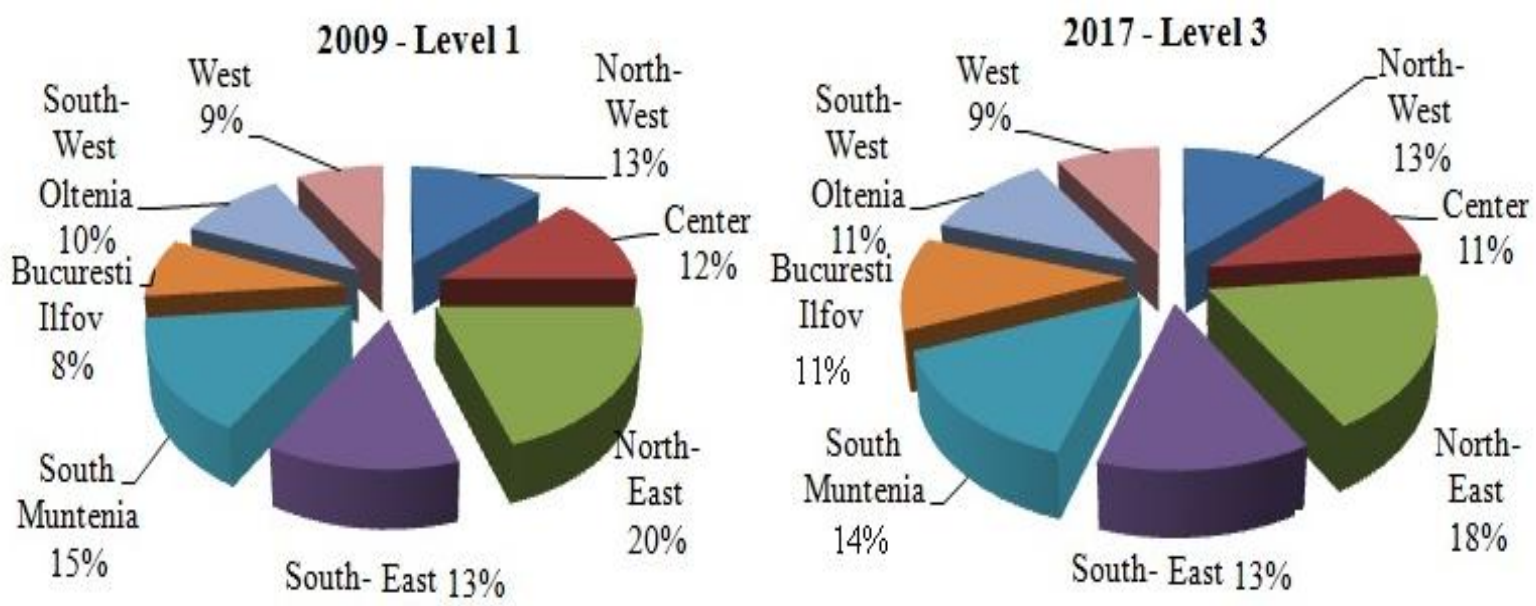

Figure 3. Evolutions of the weight of the female pre-university school population by development regions from Level 1 (2009) to Level 3 (2017) 
Thoth Publishing House

On the other hand, it is noteworthy that the 3 percent reduction in the share of pre-university school population in the North-East region (one of the disadvantaged regions of Romania), which reached the third level of education, is largely due to the migration to others regions in the country or abroad.

In the case of the female pre-university school population in 2009 in level 1 of education (Figure 3 ), both the hierarchies and the values of the weights are similar to those of the male pre-university school population.

In 2017, the year when this school population reached level 3 of education, compared to the male school population, higher values were recorded by 1 percentage point in the North_East, North-West regions (regions with significant migration, especially in male population) and Center. On the other hand, lower values by 1 percentage point were registered in the South Muntenia, South-West Oltenia and Bucharest-Ilfov regions.

Finally, but not least, it should be noted that in the West development region, (low birthweight region), both the percentage of the female and male school population have the same percentage values (9\%) in 2009 as in 2017.

\subsection{Similarities and discrepancies at county level}

Although the analysis carried out at the level of development regions has highlighted some peculiarities, these are the consequence of aggregating the results at county level, aggregations that level the disparities, fact due to the existence, within the regions, of counties with different levels of economic and social development and with implications on attitude towards education.

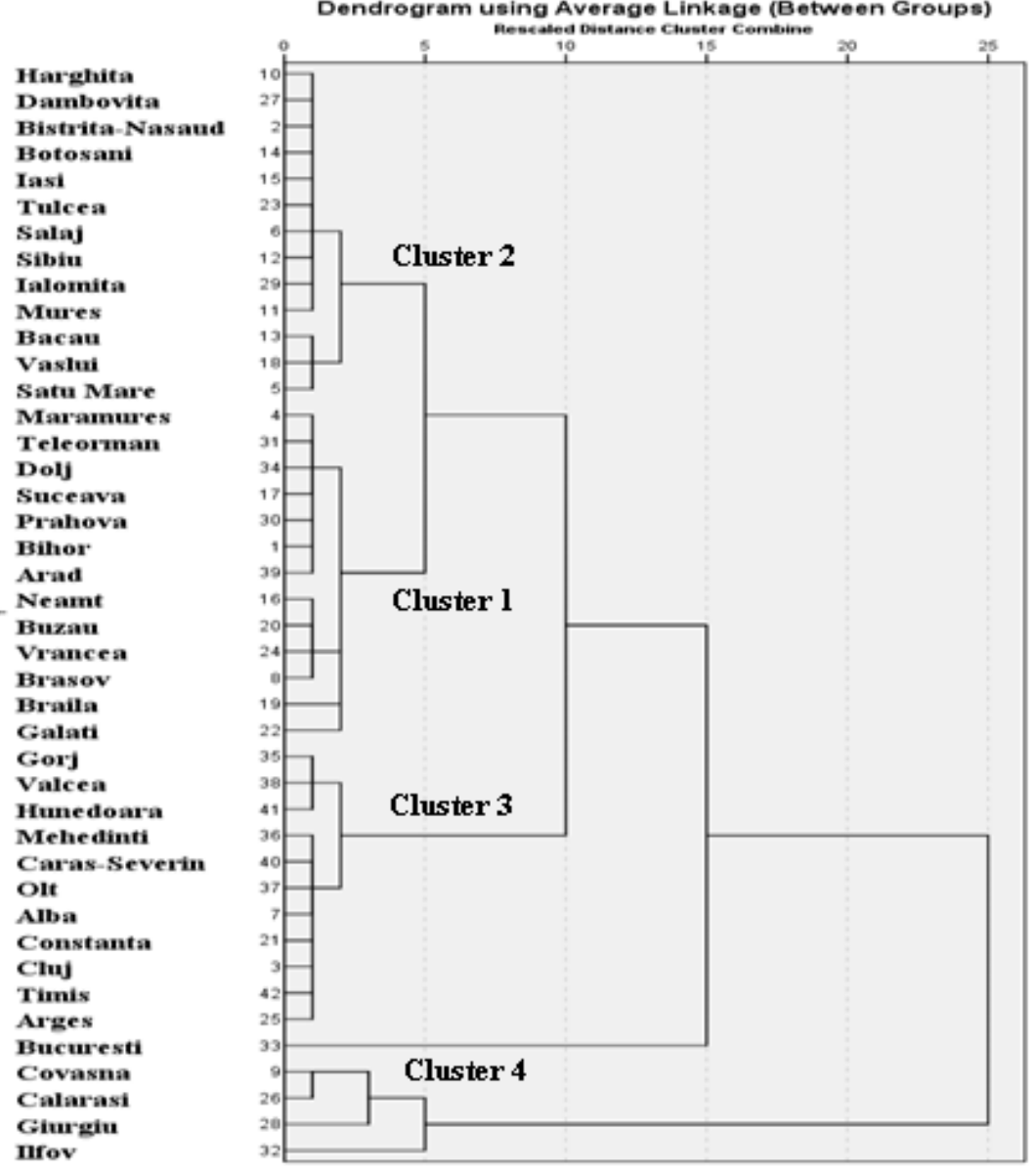

Figure 4. Dendogram of clusters generation 
Thoth Publishing House

At the county level, as a result of the analyzes carried out, it was concluded that the most eloquent grouping of the 42 counties according to the percentages of those who were in 2009 at level 1 of education, but in 2013 were no longer at level 2 of education, as well as according to the percentages of those who in 2013 were in level 2 of education, but in 2017 were no longer in level 3 of education, is the grouping in 6 clusters (figure 4), of which two contain one each exception, respectively the Municipality of Bucharest and Ilfov County. The structure of the clusters is presented in table 2 .

Tabelul 2. Grouping the counties on clusters according to the percentage of students in pre-university education who did not move from one level of education to the next higher level of education

\section{Counties}

Cluster 1 Bihor, Maramures, Brasov, Neamt, Suceava, Braila, Buzau, Galati, Vrancea, Prahova, Teleorman, Dolj, Arad

Cluster 2 Satu Mare, Salaj, Harghita, Mures, Sibiu, Bacau, Botosani, Iasi, Vaslui, Tulcea, Dambovita, Ialomita

Cluj, Alba, Constanta, Arges, Gorj, Mehedinti, Olt, Valcea, Caras-Severin, Hunedoara,

Cluster 4 Covasna, Calarasi, Giurgiu

Cluster 5 Ilfov

Cluster 6 București

To test the statistical significance of the results of the cluster grouping, both the ANOVA methodology (Test F) and the Welch and Brown-Forsythe tests were used. The application of ANOVA methodology starts from the hypothesis that the variances of the data series included in the analysis do not differ significantly. The results of testing this hypothesis are presented in table 3 .

Tabelul 3. Test of Homogeneity of Variance

\begin{tabular}{ccccc}
\hline & Levene_Statistic & df1 & df2 & Significance \\
\hline M_PR_12 & 0.290 & 3 & 36 & 0.832 \\
M_PR_23 & 0.755 & 3 & 36 & 0.527 \\
F_PR_12 & 1.071 & 3 & 36 & 0.374 \\
F_PR_23 & 1.996 & 3 & 36 & 0.132 \\
\hline
\end{tabular}

Since all the Significance values are greater than the significance threshold $(\alpha=0.05)$, the null hypothesis (Homogeneity of Variance) is accepted and, consequently, the ANOVA methodology can be applied. The results of its application are presented in table 4 .

For the threshold of significance $(\alpha=0.05)$ and the degrees of freedom 5 and 36, we obtain $F_{0,05 ; 5 ; 36}=2.477$. Considering that all $\mathrm{F}$ values (Table 4) are greater than 2,477, respectively all Sig values $<0.05$ result that the null hypothesis is rejected and the alternative hypothesis is accepted: the average values recorded at the cluster level differ significantly.

This conclusion is also reinforced by the results of the application of the second set of tests (table 5). Taking into account the values of Sig. $<0.05$, the null hypothesis is rejected. Consequently, the average values recorded at the cluster level differ significantly.

Finally, the last test before analyzing the results refers to the statistical significance of the average values obtained. The critical values of the $\mathrm{t}$ test (Student) are $t_{\frac{\alpha}{2}, n-1}=t_{0,025 ; 12}=2.560$, for cluster 1 and cluster $2, t_{0,025 ; 10}=2.634$ for cluster 3 , and $t_{0,025 ; 2}=6.205$ for cluster 4 . 
Thoth Publishing House

Tabelul 4. Results of applying the ANOVA methodology for testing the statistical significance of the average volumes recorded at the cluster level

\begin{tabular}{llllllc}
\hline & & Sum of Squares & df & Mean Square & F & Sig. \\
\hline M_PR_12 & Between Groups & 123.060 & 5 & 24.612 & 6.881 & 0.000 \\
& Within Groups & 128.757 & 36 & 3.577 & & \\
& Total & 251.817 & 41 & & & \\
M_PR_23 & Between Groups & 3263.971 & 5 & 652.794 & 58.047 & 0.000 \\
& Within Groups & 404.857 & 36 & 11.246 & & \\
& Total & 3668.828 & 41 & & & \\
F_PR_12 & Between Groups & 85.933 & 5 & 17.187 & 7.154 & 0.000 \\
& Within Groups & 86.479 & 36 & 2.402 & & \\
F_PR_23 & Total & 172.412 & 41 & & & \\
& Between Groups & 4598.897 & 5 & 919.779 & 118.458 & 0.000 \\
& Within Groups & 279.526 & 36 & 7.765 & & \\
& Total & 4878.423 & 41 & & & \\
\cline { 2 - 6 }
\end{tabular}

Since all the values of the statistics $t$ (t_statistic) are higher than the critical values corresponding to each cluster (Table 6), it results that the null hypothesis is rejected (the average values do not differ significantly from zero) and the alternative hypothesis is accepted. Consequently, the average values obtained at the level of each cluster are statistically significant.

Tabelul 5. Robust Tests of Equality of Means

\begin{tabular}{llrrrr}
\hline & & Statistic $^{\mathrm{a}}$ & df1 & \multicolumn{1}{c}{ df2 } & Sig. \\
\hline M_PR_12 & Welch & 7.147 & 3 & 9.625 & 0.008 \\
& Brown_Forsythe & 8.519 & 3 & 25.345 & 0.000 \\
M_PR_23 & Welch & 59.261 & 3 & 8.419 & 0.000 \\
& Brown-Forsythe & 64.841 & 3 & 7.845 & 0.000 \\
F_PR_12 & Welch & 9.705 & 3 & 14.572 & 0.001 \\
& Brown-Forsythe & 6.761 & 3 & 35.520 & 0.001 \\
F_PR_23 & Welch & 139.207 & 3 & 8.327 & 0.000 \\
& Brown-Forsythe & 103.199 & 3 & 5.342 & 0.000 \\
\hline
\end{tabular}

a. Asymptotically F distributed.

Of the 13 counties included in cluster 1, four belong to the South-East development region (Braila, Buzau, Galați, Vrancea), two counties belong to the North-West (Bihor, Maramures), North-East (Neamț, Suceava) and South-Muntenia (Prahova, Teleorman), and as a county from the Center (Braşov), South-West Oltenia (Dolj) and West (Arad) regions. At the cluster level, the percentage of pre-university school population who did not continue their education at level 2 is $6.20 \%$ for the male population and $6.48 \%$ for the female population.

If in the process of the transition from level 1 to level 2 of education there is a small difference of the percentage of the pre-university school population on the two sexes ( 0.28 percentage points), in the case of the transition from level 2 to level 3 of education the differences are significant. Thus, at the cluster level, the percentage of the male population that does not reach the 3rd level of education is twice that of the female pre-university school population. Analyzing the values recorded at the county level, compared to the average of the indicators at the cluster level, it should be emphasized that values above the average, at all four indicators, were recorded in Braşov, Neamţ, Galați and Vrancea counties, indicating higher percentages of those who do not accede in higher levels of pre-university education. At the opposite people, a better situation than the average at the cluster level were registered in the counties of Maramures, Suceava and Prahova.

Cluster 2 also includes 13 counties: 4 counties from the North-East region (Bacau, Botoșani, Iasi and Vaslui), 3 counties from the North-West regions (Bistrita-Nasaud, Satu Mare, Salaj) and Center 
(Harghita, Mures, Sibiu), and 2 counties in the South-Muntenia region (Dambovita and Ialomita). A first feature of the counties in this cluster is the very high percentage of those who, in the period 20132017 no longer access to the level 3 of education, accounting for over $40 \%$ of the male pre-university school population, and over $22 \%$ of the gender female.

Tabelul 6. The average values of the analyzed parameters, their confidence intervals, the results of their statistical significance testing and standard errors for clusters 1-4

\begin{tabular}{|c|c|c|c|c|c|c|c|}
\hline & Parameters & Mean & $\begin{array}{l}\text { Standard } \\
\text { Deviation }\end{array}$ & $\begin{array}{l}\text { Standard } \\
\text { Error }\end{array}$ & $\begin{array}{c}\text { Confidence } \\
\text { interval }(95 \%)\end{array}$ & t_stastic & Sig. \\
\hline \multirow{4}{*}{ 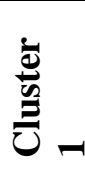 } & M_PR_12 & 6.20 & 2.004 & 0.556 & 1.21 & 11.151 & 0.000 \\
\hline & M_PR_23 & 32.46 & 3.005 & 0.833 & 1.82 & 38.955 & 0.000 \\
\hline & F_PR_12 & 6.48 & 1.587 & 0.440 & 0.96 & 14.715 & 0.000 \\
\hline & F_PR_23 & 14.97 & 3.201 & 0.888 & 1.93 & 16.858 & 0.000 \\
\hline \multirow{5}{*}{ 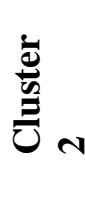 } & M_PR_12 & 7.68 & 1.714 & 0.475 & 1.04 & 16.157 & 0.000 \\
\hline & M_PR_23 & 41.87 & 2.975 & 0.825 & 1.80 & 50.743 & 0.000 \\
\hline & F_PR_12 & 6.98 & 1.600 & 0.444 & 0.97 & 15.728 & 0.000 \\
\hline & F_PR_23 & 23.51 & 2.389 & 0.663 & 1.44 & 35.482 & 0.000 \\
\hline & M_PR_12 & 4.31 & 2.030 & 0.612 & 1.36 & 7.048 & 0.000 \\
\hline \multirow{3}{*}{ 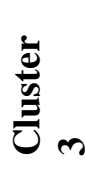 } & M_PR_23 & 24.09 & 3.796 & 1.144 & 2.55 & 21.053 & 0.000 \\
\hline & F_PR_12 & 4.88 & 1.581 & 0.477 & 1.06 & 10.246 & 0.000 \\
\hline & F_PR_23 & 5.33 & 2.061 & 0.621 & 1.38 & 8.577 & 0.000 \\
\hline \multirow{4}{*}{ 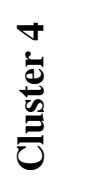 } & M_PR_12 & 8.40 & 1.428 & 0.825 & 3.55 & 10.191 & 0.009 \\
\hline & M_PR_23 & 51.79 & 4.808 & 2.776 & 11.94 & 18.655 & 0.003 \\
\hline & F_PR_12 & 8.01 & 0.534 & 0.308 & 1.33 & 25.983 & 0.001 \\
\hline & F_PR_23 & 39.38 & 4.774 & 2.756 & 11.86 & 14.285 & 0.005 \\
\hline
\end{tabular}

For a coefficient of $95 \%$ confidence, level 3 education lost between $40.07 \%$ and $43.67 \%$ of the male school population that in 2013 was in level 2 of education and between $22.07 \%$ and $24.96 \%$ of the female school population that in 2013 was find in level 2 education. The most unfavorable situations were registered in the counties of Satu Mare (losses of $44.60 \%$ of the male school population and $27.58 \%$ of the female school population), Bacau (losses of $48.02 \%$ of the male school population and $23.07 \%$ of the female school population) and Vasile female school) (losses of $46.19 \%$ of the male school population and $24.97 \%$ of the female school population).

The third cluster contains 11 counties out of which, with the exception of Cluj and Alba counties, located in the North-West and Center regions, the other 9 counties are from southern Romania and Banat. The characteristic of the counties of this cluster is the fact that, compared to the other clusters, they registered the lowest percentage of the pre-university school population that do not enter the levels 2 , and 3 of education. Thus, in the case of the transition from level 1 to level 2 of education in the period 2009-2013, the losses were $4.31 \%$ for the male school population (less than 1.44 times compared to cluster 1, 1.78 times compared to cluster 2, and 1.95 times compared to cluster 4) and $4.88 \%$ for the female school population (lower than 1.33 times compared to cluster 1, 1.43 times compared to cluster 2, and 1.64 times compared to cluster 4).

On the other hand, a general feature, which is also recorded here, is that at the transition from level 2 to level 3 of education, the weight of the male school population that is lost is much higher than the weight of the female school population. Thus, $24.09 \%$ of the male school population that was in 2013 in level 2 of education is no longer found in 2017 in level 3 of education. However, the situation is significantly better than in the case of the other three clusters, the level recorded being less than 1.35 times compared to cluster 1, 1.74 times compared to cluster 2, and 2.15 times compared to cluster 4 .

Another characteristic of this cluster is the very small percentage, compared to the other clusters, of the female school population, which in 2013-2017 did not move from level 2 to level 3 of education 
(5.33\%). This percentage is less than 2.81 times compared to cluster 1, 4.41 times as compared to cluster 2 , and 7.39 times as compared to cluster 4 .

Cluster 4 groups three counties, one from Center (Covasna) and two from southern Romania (Calarasi and Giurgiu) with the most unfavorable results regarding the pre-university school population during the analyzed period. Thus, in the transition from level 1 to level 2 of education, in the period 2009-2013, 8.40\% of the male school population and $8.01 \%$ of the female gender school population were lost on average. If we consider the $95 \%$ confidence interval (Table 6), the estimated loss could be $11.95 \%$ for the male school population and $9.34 \%$ for the female gender school population.

With regard to the transition from level 2 to level 3, the losses of the school population were particularly high. Thus, $51.79 \%$ of the male school population that in 2013 was in level 2 of education, in 2017 is no longer in level 3 of education.

A similar situation was registered in the case of the female school population, the loss here being $39.38 \%$. One of the causes of these large losses of population during the pre-university cycle is the economically precarious situation of the counties included in this cluster.

The cluster analysis performed above did not include Ilfov County and Bucharest Municipality. Although, as evidenced in the dendogram in Figure 4, Ilfov County could have been included with certain reserves in cluster 4 , I have forgotten that due to the significant changes and transformations that took place both in Bucharest and around it, the data included in the analysis regarding these they do not provide significant information for characterizing the losses of pre-university school population in these entities during the analyzed period, imposing a more detailed approach that is the subject of a separate analysis.

\section{Conclusions}

The most important conclusion of this study is the high rate of loss of pre-university school population during the transition from one level of education to another in both the development regions and the counties of Romania, a conclusion underlined in the research undertaken by Oprea $[15]$.

One cause of this situation is the discrepancy between counties in terms of the levels of economic and social development, implicitly the endowment levels of the educational institutions and the access to the labor market. Also, an important aspect to consider is the fact that a good part of the attitude towards education is formed from pre-school education (level 0 ISCED), how this is done being important for both the child and for the family, with a direct impact on future school results.

Finally, but not least, the adequate funding oriented both to the student by placing him in a flexible and friendly environment and to teachers, by recognizing their role in shaping the character of the human being.

It should also be emphasized that this phenomenon of increasing the rate of loss of pre-university school population during the transition from one level of education to another has a general character manifesting itself both in Romania [16-19]. and at the level of other states [20-22].

The general conclusion of the study is that maintaining the characteristics of the current education system cannot lead to the achievement of the objectives of the Europe 2020 strategy [23] Romania probably remaining in the last place and from this point of view.

\section{References}

[1]Dima I C, Ciurea Vl and Man M 2010 Positioning Of Pre-University Education Into the National System of Education of Romania Polish Journal of Management Studies 1 issue 1 pp. 102-110

[2] Aceleanu M I, Serban A C, Burghelea C 2014 Perspectives on Education in Romania in the Context of Europe 2020 Strategy Management Strategies Journal 26 issue 4 pp. 774-781

[3] Crăciun L 2012 The future and the new face of economy, Theoretical and Applied Economics Journal Volume XIX, No. 1(566), pp. 65-72 
[4] Nistoreanu T and Răduț E 2010 Strategies on Preparation by Education Pre-University of Resources Work for the Correlation of Request with Offer on Labor Market Annals of University of Craiova - Economic Sciences Series 1 issue 38 pp. 134-142

[5] Avram B and Sobou S 2016 The Influence of Education on the Entrepreneurial Behaviour in Romania Annals of Faculty of Economics, 1 issue 1 pp. 447-456

[6] Corbu L C and Baicu C S 2016 Current Situation of Human Resources in Romanian PreUniversity Eucation Context of E.U. Integration, EcoForum, 5, issue 1

[7] Pătrașcu A 2016 Aspects of the Evolution of the Existing Pre-university Education at Regional Level in 1996-2014 Ovidius University Annal Economic Sciences Series XVI, issue 1 pp. 583-588

[8] Tusa A, Voinea C S and Dumitrascu D D 2013 Research on Romanian Manager Training in Pre-University Education Annals - Economy Series 3 issue pp. 97-100

[9] Logofatu M and Stefanescu C 2016 Particularities Of Human Resource Management in The Romanian Secondary Education Annals - Economy Series 6 issue pp. 77-84

[10] Mascu M 2017 The Role of Swot Analysis in the Projection of the Educational Offers Regarding Pre-University Institutions Business Excellence and Management 7 issue $1 \mathrm{pp}$. $28-44$

[11] Issa C F and Popescu D M 2012 Modern Approaches in the Pre-University Educational Institutions Proceedings of the International Management Conference 6 issue 1 pp. 419425

[12] National Insitute of Statistics, România http://www.insse.ro/cms/en

[13] International_Standard_Classification_of_Education https://ec.europa.eu/eurostat/statisticsexplained/index.php/International_Standard_Classification_of_Education_\%28ISCED\%2 9 Accesed on 2019 June 15.

[14] http://statistici.insse.ro:8077/tempo-online/\#/pages/tables/insse-table SCL103F - Enrolled population, by level of education, gender, macroregions, development regions and counties. Accesed on 2019 June 20.

[15] Orea C, Popescu D M, Gabrea R E and Stoica A 2017 A Cluster Analysis Of The Romanian Counties in Terms of School Population Didactic Staff and Number of Classes, Proceedings of the International Management Conference 11 issue 1 pp. 378383

[16] Ciumas C, Urean C A, Muresan G M and Armean G 2017 Education and Employment Rate in Romania, Annals of Faculty of Economics 1 issue 1 pp. 81-86

[17] Lorenz-Rodriguez J, Faina A and Bolea C G 2011 The Effects of Economic Geography on Education in Romania Theoretical and Applied Economics XVIII(2011) issue 2(555)p p. $101-110$

[18] Togoe D 2010 Romanian Pre-University Education Financing. Ideal vs. Reality Annales Universitatis Apulensis Series Oeconomica 1 issue 12

[19] Haisan A A 2015 Profile of Romanian pre-university teachers, a social media approach Romanian Journal of Economics $\mathbf{4 0}$ issue 1(49) pp. 281-298

[20] Yavuz M and Karaca S 2015 Teachers and Principal Communication in Pre-School Education Proceedings of Teaching and Education Conferences, International Institute of Social and Economic Sciences No 2404110

[21] Klyachko T, Avraamova E, Loginov D, Polushkina E, Semionova E and Tokareva G 2019 Monitoring of efficiency of school education. Pre-school education: accessibility and quality, Published Papers, Russian Presidential Academy of National Economy and Public Administration.

[22] Berlinski S, Galiani S and Gertler P 2009 The effect of pre-primary education on primary school performance Journal of Public Economics 93 issue 1-2 pp. 219-234

[23] European Council. Europe 2020: A new European strategy for growth and jobs. Brussels, European Council, 2010 